\title{
BioOne COMPLETE
}

\section{From worship to subjugation: Understanding stories about bears to inform conservation efforts}

Authors: Hughes, Courtney, Frank, Beatrice, Melnycky, Natalka A., Yarmey, Nicholas T., and Glikman, Jenny Anne

Source: Ursus, 2020(31e15) : 1-12

Published By: International Association for Bear Research and Management

URL: https://doi.org/10.2192/URSUS-D-19-00002.2

BioOne Complete (complete.BioOne.org) is a full-text database of 200 subscribed and open-access titles in the biological, ecological, and environmental sciences published by nonprofit societies, associations, museums, institutions, and presses.

Your use of this PDF, the BioOne Complete website, and all posted and associated content indicates your acceptance of BioOne's Terms of Use, available at www.bioone.org/terms-of-use.

Usage of BioOne Complete content is strictly limited to personal, educational, and non - commercial use. Commercial inquiries or rights and permissions requests should be directed to the individual publisher as copyright holder.

BioOne sees sustainable scholarly publishing as an inherently collaborative enterprise connecting authors, nonprofit publishers, academic institutions, research libraries, and research funders in the common goal of maximizing access to critical research. 


\title{
From worship to subjugation: Understanding stories about bears to inform conservation efforts
}

\author{
Courtney Hughes ${ }^{1,6,7}$, Beatrice Frank ${ }^{2}$, Natalka A. Melnycky ${ }^{3}$, Nicholas T. Yarmey ${ }^{4}$, and \\ Jenny Anne Glikman ${ }^{5}$
}

\author{
${ }^{1}$ University of Alberta, Department of Renewable Resources, 701 General Services Building, 9007-116 Street, NW \\ Edmonton, AB T6G 2H1, Canada \\ ${ }^{2}$ Capital Regional District of Victoria, 490 Atkins Avenue, Victoria, BC V9B 2Z8, Canada \\ ${ }^{3}$ Government of Alberta, Environment and Parks, 962196 Avenue, Peace River, AB T8S 1T4, Canada \\ ${ }^{4}$ University of Alberta, Augustana Campus, 4901-46 Avenue, Camrose, AB T4V 2R3, Canada \\ 5 Instituto de Estudios Sociales Avanzados (IESA-CSIC), Campo Santo de los Mártires 7, 14004 Córdoba, Spain \\ ${ }^{6}$ Government of Alberta, Environment and Parks, 9607 Shand Avenue, Grande Cache, AB TOE OYO, Canada
}

\begin{abstract}
Throughout history and across their geographic distribution, bear species (Ursidae) have been portrayed and valued for their beauty, physical power, or ecological significance, while concurrently disliked and feared for their ferocity, negative economic impacts, and safety risks they can pose to people. How bear species are depicted in stories—including myths, legends, fables, or tales - can influence how people come to value bears and act toward them. It is our belief that reviewing the stories people tell about bears can be useful in understanding people's proclivity to conservation action, given that stories told about bears can be a powerful demonstration of how local culture influences human relations with wildlife. We conducted a review of English-language literature for stories about bears across their global range, to better understand how these stories reflect human thought and imagination, experiences, and behaviors concerning bears. We identify 4 themes about bears as told through different narratives-including kinship, utilitarianism, threat, and political bears-and illustrate how understanding stories told about the wild animals that share our lives can provide important insights into developing conservation policy and action.
\end{abstract}

Keywords: bears, conservation, human-bear interactions, policy, relations, sociocultural values, stories, theme

DOI: 10.2192/URSUS-D-19-00002.2

Ursus 31:article e15 (2020)

It is widely understood that human-large carnivore relationships are complex, ranging from reverence to vilification, conflict to coexistence (Madden 2004, Hill 2015, Redpath et al. 2015, Ives et al. 2017, Frank et al. 2019, Hughes et al. 2020, Morehouse et al. 2020). Increasingly, human dimensions research is moving beyond attitudinal assessments to examine the role that broader cultural beliefs, values, and practices play in conservation governance and achieving desired outcomes (Knight 2001, Dickman 2010, Riley 2010, Mukul et al. 2012, Walsh and Goldman 2012, Young et al. 2015, Camino et al. 2016, Ives et al. 2017, Fraser-Celin et al. 2018, Infield et al. 2018, Hughes and Nielsen 2019). This includes understanding the cultural and emotional connections people have to different wild animals, which can invoke affective and behavioral responses (Hall et al. 2012, Frank et al.

${ }^{7}$ email: ckhughes@ualberta.ca
2017, Ives et al. 2017). Given this, we suggest exploring how different animal species, and specifically bear (Ursidae) species, feature in the hearts and minds of people, which can offer insights into conservation policy and practice (Gottschall 2012, Infield et al. 2018, Sousa et al. 2018). We consider, then, that the different stories people tell about bears may hold more importance for local cultural beliefs and practices than do objective truths (Fritts et al. 2003, Gottschall 2012, Hall et al. 2012, McLellan et al. 2017, Fernández-Llamazares and Cabeza 2018).

We use 'stories' to represent myths and legends (often sacred explanation of beliefs and ritual practices), folklore (rules and social practices governing a group), tales (verbal history and accounts), taboos (instruction on morality and conduct), and even modern fiction (Bascom 1954, Majasan 1969, Jalais 2008, Gottschall 2012, Zemmelman 2012, Glikman et al. 2019). Stories have been told throughout history to help people make sense of their world, to organize knowledge, share beliefs, 
transmit values, teach lessons or skills, offer amusement, and set forth socially acceptable behaviors (Jones 1994, Bronner 2007, Hill and Webber 2010, Gottschall 2012, Zemmelman 2012, Good et al. 2017, Sousa et al. 2018). Examining the stories people tell about bears can illuminate what these animals mean to people, which may assist in efforts to design conservation activities that resonate with local belief systems, or if appropriate, dispel myths and encourage change (Bowen-Jones and Entwistle 2002, Fraser et al. 2006, Dunham 2007, Harel 2009, Riley 2010, Gottschall 2012, Infield et al. 2018, Schneider 2018, Brittain et al. 2020). We take stories to be reflective of cultural beliefs and norms and, through their telling, can influence the attitudes and behaviors of people (Gottschall 2012, Glikman et al. 2019).

Examining the stories people tell about wild animals has indeed been part of a growing body of literature. For example, examining different African narratives about lions (Panthera leo) has provided insight into honoring these felines for their power and rationalizing ritual killing as a passage into manhood (Dickman et al. 2015). Across parts of Central and South America, stories about jaguars (P. onca) yield insights into the worshiping of cats as ancestors, condemning them as savage man-eaters, or, at present, their symbolic representation of land-use conflicts between ranchers and conservationists (Roe 1998, Zimmermann et al. 2005, Carvalho and Pezzuti 2010, Fort et al. 2018). Figari and Skogen (2011:13) suggest that the representations of large carnivores to people, as manifested through different forms of story, are "framed by consensual cultural beliefs," which in turn act to influence individual and social practices (Bascom 1954, Descola 1996, Gottschall 2012, Dhee et al. 2019). In this case, we suggest that exploring the meanings that stories about bears convey to people can help conservationists develop policy action that supports positive, desired outcomes and avoid unintended consequences through cultural insensitivity (Hill and Webber 2010, Tegel 2011, Baynes-Rock 2015, Good et al. 2017, Brittain et al. 2020).

Without a doubt, bears are a charismatic megafauna capable of invoking a range of emotional and behavioral responses from people across the world; and indeed, effigies, cave paintings, clothing, and other artifacts point to the importance of human-bear relations (Gibbon 1964, Elms 1977, Kaczensky et al. 2004, Blomberg 2007, Pastourneau 2011, Frank and Silva 2012, Grayson 2012). In reviewing stories about bears, whether Ursa Major to Callisto, or Paddington Bear to Golidlocks, we believe conservationists can use this information to develop conservation actions that appeal to human culture and values (Yoon 1979, Knight 2000, Bowen-Jones and Entwistle
2002, Dunham 2007, Harel 2009, Riley 2010, Infield et al. 2018, Dhee et al. 2019). Although we understand that local culture may undermine conservation efforts by perpetuating negative discourse and behavioral norms that are contrary to conservation objectives, we also posit that when thoughtfully considered and respected, local cultural values, attitudes, and practices, as transmitted through story, provide an opportunity to generate conservation support (Mattson et al. 2006, de Pinho et al. 2014, Matejova 2015).

\section{Methods}

Some of the more common representations of nonhuman animals in literature are found in story, whether fables, legends, myths, or tales (Tatar 2002, Harel 2009, Varga 2009, Gottschall 2012). People use both their imagination and cultural stereotypes when writing about nonhuman animals, and often anthropomorphize species (Foltz 2010, Baynes-Rock 2015). In particular, bears are described in metaphor relative to their human-like traits and behaviors, and can be honored through ceremony or totems, or feared for the risks they can pose (Brunner 2007, Lescureux and Linnell 2010). We determined that to better understand the meanings ascribed to bears, or meanings inherent in the stories people tell about them, a qualitative exploratory approach to reviewing bear stories would be most appropriate (Fraser et al. 2006, Gergen 2015, Haddaway et al. 2015, Frank et al. 2017, FraserCelin et al. 2018, Lute and Carter 2020). This approach was appropriate given that it provides researchers the flexibility to describe the data rather than constrain data to defined categories (Lute and Carter 2020). To qualitatively explore bear stories, and enable the emergence of meaning through our review, we focused on stories available online in the English language that portrayed bears over space and time, including human beliefs about bears (e.g., spirituality, ecological processes), values ascribed to bears (e.g., power, food), and practices related to bears (e.g., ceremony, taboos; Descola 1996, Frank 2016, Dhee et al. 2019, Lute and Carter 2020). We acknowledge the limitations that an online English-language search imposes, including the potential for loss of nuances with translation, and loss of temporal significance when told in a specific cultural context. However, we felt it important for the search to be geographically and temporally expansive in order to explore the diversity of stories available.

We used a keyword search (bear, story, folklore, myth, legend, ceremony, taboo, use, spiritual, children) with Boolean operators 'AND,' 'OR,' and 'NOT' (café, 
sports, mascot, clothing, jewelry) with an open date range in Google Scholar (https://scholar.google.com/), JSTOR (https://www.jstor.org/), and the Web of Science (https://clarivate.com/webofsciencegroup/solutions/webof-science/ [Haddaway et al. 2015, Bhatia et al. 2019, Lute and Carter 2020]). To screen documents for suitability, we read the titles of the first 250 documents, followed by reading the abstracts or introduction to confirm relevance to our review (Fraser et al. 2006, Lute and Carter 2020). It is important to note that we largely excluded research papers that reported only on attitudinal studies toward bears because we considered these to be out of scope in understanding the broader cultural representations of bears as told through forms of story. We also excluded articles, books, and gray literature (e.g., reports, theses), or news stories that represented bears as art or mascots. We also largely excluded the dearth of popularized books on bear attacks, because we considered these sensational and potentially biased in their reporting. Further, we recognize the importance of bear symbolism or bear effigies as part of cultural storytelling about the significance of bears to people.

We reviewed 80 documents that aligned with the outlined objectives (Supplemental material A). During the first read-through, we made preliminary notes on the beliefs, values, knowledge, and practices associated with bears described in the documents (Fraser et al. 2006). We compared these descriptions and condensed them into categorical themes, using naming conventions from the literature (Fraser et al. 2006). We reread each document and where possible assigned it to a single theme based on the prevailing meaning that best captured how bears were portrayed and what bears represented (Table 1; Fraser et al. 2006, Haddaway et al. 2015, Bhatia et al. 2019, Dhee et al. 2019). That said, some pieces of literature crossed thematic boundaries and, as such, were captured in one or more themes.

With our review, we acknowledge that the meanings and intent of a story can change each time it is told, depending on the narrator's or interpreter's lens (Gottschall 2012), and we recognize these changes can affect conservation efforts (e.g., reintroduction of bears to a landscape where they were otherwise extirpated). Our review thus reflects our interpretation of the stories people tell about bears as we reviewed literature presented here. We do, however, acknowledge that other readers may have different interpretations of these stories that are worthy of discussion (Fraser et al. 2006, Haddaway et al. 2015), as well as acknowledge the limitations of a western scientific interpretation of culturally rich stories (Infield et al. 2018).

\section{Results}

Our qualitative exploratory review revealed 4 main themes that describe the meanings inherent to the stories people tell about bears (Table 1). Below we describe each theme and discuss each discretely (Fraser et al. 2006). We note that our constructed boundaries between themes are artificial, with shared concepts, such as respect or fear, spanning different themes. We recognize the plurality of human beliefs and values for bears as told through forms of story, and that these can be difficult to assign to one thematic category.

\section{Bears as kin}

Stories that fit within this theme frame bears as ancestors, referencing the morphological, temperament, and other characteristic similarities of bears to humans, including a plantigrade gait, gestation period, maternal care, intelligence, and individualism. These stories also include lessons to equip people to live alongside their bear-kin, including direction on avoiding conflict situations but simultaneously revering these animals for their power and prowess. These stories also reflect origins, referencing human-bear pairings that resulted in semi-ursine offspring that were believed to establish royal bloodlines or become formidable warriors. Frank (2015:24) writes about early hunter-gatherer communities that venerated the bear:

"Bears and native people lived together on the continent of Europe for thousands of years. Both walked the same trails, fished the same salmon streams, dug roots from the same fields, and year after year, harvested the same berries, seeds and nuts."

Invoking the name of the bear was often believed to signal virtuous qualities or spiritual authority in the bearer, as seen with stories about Saint Ursula or King Arthur. Similarly, Indigenous clans around the world honored the bear through ceremonies and taboos against killing, which can be interpreted to both revere and respect the bear. Transformation and healing appear to be a central tenet of bear spiritualism, associated with effigies and cults across North America, Europe, and Asia. Whereas reverence and ceremony often honor the life of a bear, this is not to say bears were not killed-tales from the Japanese Ainu, North American Pueblo, or Yavapi tribes speak of ritualistically killing bears as part of festivities, while respecting the animal's sacrifice.

\section{Bears as utilitarian}

Bear stories within this theme narrate the utilitarian value of bears to people. Utilitarian value of bears 
Table 1. Themes and related concepts found in stories about bears across their global range, with source literature (available in Supplemental material A). Note the boundary-spanning themes that some literature occupied.

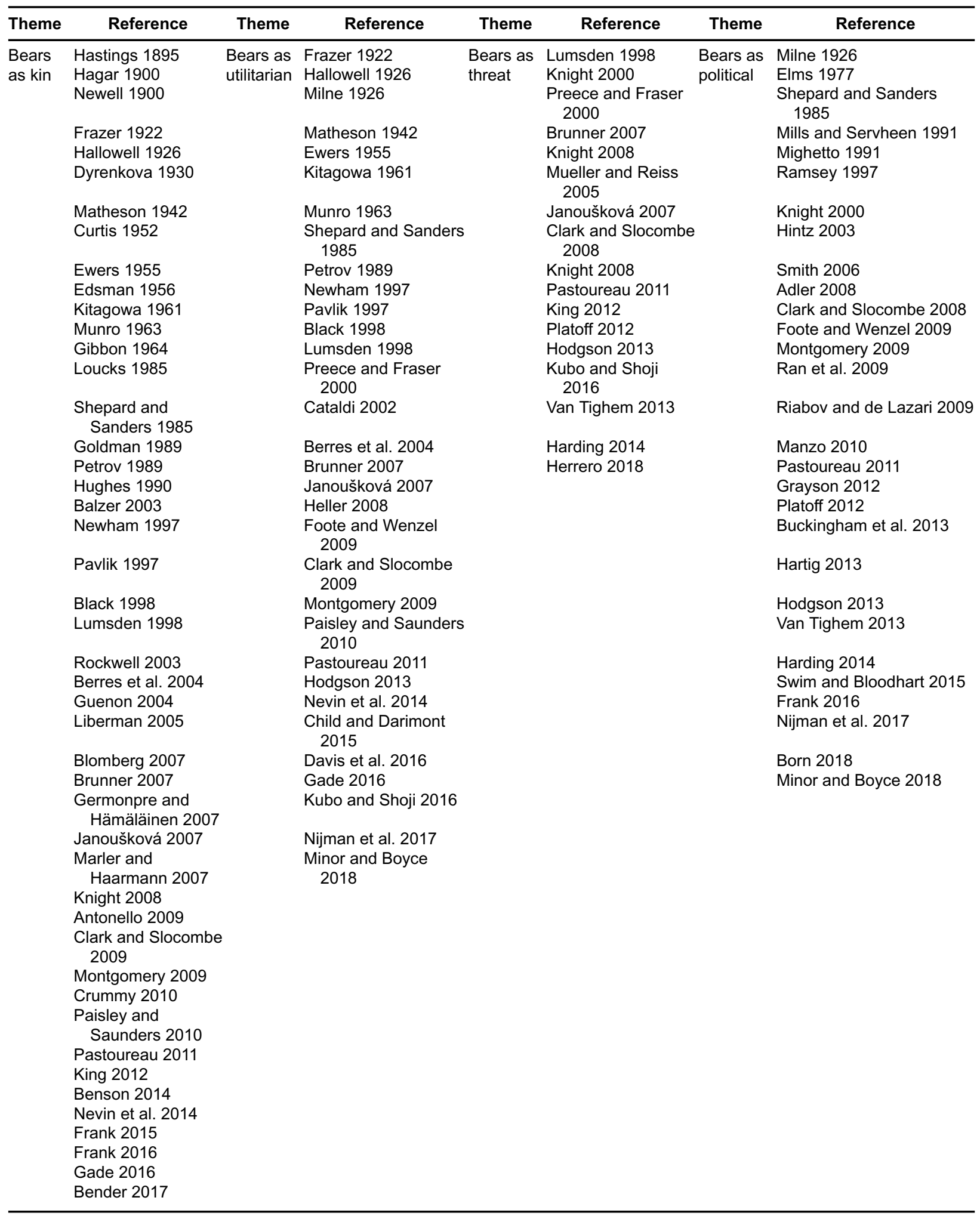


included the material form, with stories that describe the reverence of bears and their sacrifice to fulfill human needs for food, fur, or certain body parts in traditional medicine. These stories also reflect the intangible value of bears-such as when hunted during a rite of passage or quest—or serve as a means to address 'problem animals' reflective of the traditions and toils of human livelihoods in bear country, with stories expressing the subjugation and domination of bears as representative of man conquering wild nature. These stories also reflect utilitarianism, presenting bears as a source of entertainment when describing captive and starved bears used in 'sporting' arenas or circuses. Further, early Christian doctrine positioned bears as slovenly beasts, barbaric kidnappers, or immoral animals. This framing apparently used the bear to teach morality, but still positioned humankind as having dominion over the bear. Lastly, bears have been used in children's tales, also to instruct or act as a companion (e.g., The Jungle Book, Winnie the Pooh).

\section{Bears as threat}

Stories that describe bears in terms of a threat reflect the human safety risks, negative economic impacts, and pests or problems that bears can symbolize. This prominently includes fear of bears, used to invoke caution and in some instances respect for the animal. However, stories about fearing bears can also contribute to indiscriminate or retaliatory killing. As Platoff (2012:101) suggests,

"very rarely does the bear get the better end of encounters, no matter if they are with other wildlife, domestic animals or humans. Usually, the bear suffers indignity, exploitation, or even death at the hands of other characters in the stories."

That said, the threat theme also includes narratives of the role people play in preventing bear attacks, and suggests the benevolence of bears in their tolerance of human interaction. Certainly, we found indication that a nonaggressive encounter with a bear can have a profound effect on a person's perception and values.

\section{Bears as political}

These stories feature bears as a politicized actor, with narratives using bears in war propaganda, national pride, or to symbolize the debate over the burden or opportunity of bear conservation actions. This ranges from using bears as symbols for aggression and rapacious power to invoking national pride and softening international perspectives, or inciting fear and anxiety or paranoia. Some children's tales can be viewed with a political lens, expressing resilience against alien invaders (i.e., Goldilocks and the Three Bears) or narrating tensions related to immigration and identity (i.e., A Bear Called Paddington).

Within other themes, there was minimal perceivable distinction between a specific bear species and associated cultural beliefs and values. In contrast, in stories fitting within the political theme, very apparent narratives specific to the bear species emerged. This included brown (grizzly) bears (Ursus arctos) in North America and across parts of Europe, with a narrative representing them as antagonistic symbols in human conflict and conservation governance disputes. Specific narratives are also associated with 2 of the most recognizable global icons - the giant panda (Ailuropoda melanoleuca) and polar bear (U. maritimus) — used to symbolize the perils facing humanity, calls to conservation action, the possibility of positive achievements, and diplomacy between nations (e.g., panda diplomacy).

\section{Practical considerations}

Without question, bears occupy a special place in human imagination and experience, as demonstrated by our qualitative exploratory review (Ingold 1994, Richie et al. 2012, Can et al. 2014, Harding 2014, Wilson et al. 2014). The stories we reviewed about bears weave between the subjective and objective, speaking of origins, ceremony and taboos, lessons and significant life events, consumptions, entertainment, and threats or risks, all of which appear to help people make sense of their relationship to these animals (Ingold 1994, Hobson 2007, Zemmelman 2012, Dhee et al. 2019, Hughes and Nielsen 2019). This includes bears' anthropomorphized qualities, which can be thought of as a grounding force between nature and humankind, as well as a spiritual bridge between people and divinity (Shepard and Sanders 1985, Black 1998). For example, different Indigenous cultures around the world viewed bears as direct ancestors, espousing kinship values or anthropomorphized women and bears, as reflected in the story "Bear Mother" (Barbeau 1946). Bears were also seen as spiritual guides, bridges between life and death, or symbols of gallant bravery and protectors of people as told in the Indigenous Finnish story "Kalevala" (Shepard and Sanders 1985, Clark and Slocombe 2009). In Northern European and Himalayan cultures, legends tell of half-bear, half-human pairings, giving rise to myths like the Yeti and stories referencing respect for these creatures' strength and power (Werness 2004, Brunner 2007). And a Norwegian legend references the fearsome warrior berserkers (ber, bear and serkr, coat or shirt), calling forth the symbolic potency of the bear in battle (Bieder 2007, Brunner 2007). Classical Greek literature also depicts the importance of bears, reflected in myths and tales

\section{Ursus 31:article e15 (2020)}


like Artemis or Callisto, or Aesop's Fables where bears are represented as benevolent characters that illustrate social injustices in the 6th Century B.C. (Barbeau 1946, Shepard and Sanders 1985). Indeed, in the late 19th and early 20th Centuries, bears became protagonists of children's tales, with Goldilocks and the Three Bears interpreted as a cautionary lesson or to illustrate a cohesive family unit demonstrating resilience against an alien invader, to Winnie the Pooh depicting the bear as an endearing and compassionate friend to a child otherwise alone (Elms 1977, Shepard and Sanders 1985, Tatar 2002, Grayson 2012). Even the classic children's teddy bear is suggested to have been born from U.S. President Theodore Roosevelt's hunting trip, becoming a symbol of the sublime that reverses the ethos of hunters and conquering wilderness to providing a comfort to children (Varga 2009, King 2012). On the other hand, hunting bears has been argued to vary between representing a manifestation of human ego, vanity, or pride to reflecting culturally important practices or subsistence lifestyles (Knight 2000, Child and Darimont 2015).

Indeed, bears appear to have historically occupied an array of symbolic meaning, from magnificent to endearing, amusing to gullible, divine to evil, fearsome to detestable, across human culture (Mattson et al. 2006, Janoušková 2007). These meanings are rooted in particular socio-cultural contexts and passed between generations, which in turn manifest in popular beliefs and influence people-who they are, what they believe, and what actions they take relative to bears (Kellert 1994, Mattson et al. 2006, Chamberlain et al. 2012, Hughes and Nielsen 2019). Understanding the cultural context and range of psychological dispositions in present-day bear management will undoubtedly influence the success of conservation policy, in particular the values, demands, and expectations people have as they negotiate their relationship with bears (Head et al. 2005, Clark and Rutherford 2014, Hughes and Nielsen 2019). Certainly, when considering the complexity of designing and implementing conservation policy for bears, one cannot ignore the influence that culturally shared stories can have on people's attitudes and behaviors (Yoon 1979, Head et al. 2005, Mattson et al. 2006, Schneider 2018).

For example, kinship or spirituality connections, or the aesthetic attractiveness of bears, may serve to foster a conservation ethic (de Pinho et al. 2014, Dickman et al. 2015, Good et al. 2017). Even concepts like 'personhood,' ascribed to bears given anthropomorphic attributes, may further conservation efforts (Staker 2017). Although mainstream western science appears reluctant to employ bear anthropomorphism in conservation, our review indicates this conceptualization has been a fundamental part of valuing wild animals across cultures and over time within stories of kinship, spirituality, and relational reciprocity, and may thus serve conservation purposes (Fernández-Llamazares and Cabeza 2018, Young et al. 2018). Certainly, we can see anthropomorphism at play when considering the narratives and symbolism of political bears, whether signaling national pride or representing personal identity (Ramsey 1997, Mullin 1999). For example, brown (grizzly) bear narratives have been shown to symbolize politicized debate over the burden or opportunity that bear conservation can impart on people's livelihoods and wellbeing in North America and Europe (Glikman et al. 2019, Hughes and Nielsen 2019, Hughes et al. 2020). In a case study from Alberta, Canada, the narratives largely shared by different people about their relationship with grizzly bears reflected the potential impact bears had on human livelihoods and wellbeing, specifically under the situation of an imposed conservation recovery policy (Hughes and Nielsen 2019, Hughes et al. 2020). In this policy context, although the majority of people expressed they generally 'liked' bears, conservation policy was criticized for its lack of attention to supporting people above the needs of bears. The giant panda is another example of politicizing bears, used as both a symbol for conservation efforts and arguably success, as well as a representation of political diplomacy through China-global relations (Ran et al. 2009, Buckingham et al. 2013, Hartig 2013).

Mattson et al. (2006) highlight that contradictions between policy direction and public expectations can lead to contentious management contexts. Local people require some level of involvement in policy decisionmaking, with open communication about conservation requirements and human wellbeing (Clark 2002). One mechanism to help achieve this can be implementing collaborative policy and governance arrangements to foster positive dialogue, co-learning, and pro-bear attitudes and behaviors (Wondolleck and Yaffee 2000). Moreover, policy considerations should include providing financial support, materials, and supplies to implement conservation actions, timely, fair, and culturally acceptable compensation for livelihood impacts suffered from bear damages, and hands-on assistance to implement mitigations where necessary. We also want to point to the continued importance of educational programing in conservation policy. Indeed, managing agencies would benefit by distributing culturally relevant information on bear biology, legislation, and management direction, as well as by designing and delivering programs that engage people within a participatory role, such as contributing to pop- 
ulation monitoring or habitat securement. Face-to-face delivery in particular can help facilitate positive human relationships built on trust, reciprocity, and exchange (Pretty and Smith 2004). Overall, addressing issues of transparency between government and public, increasing peoples' accurate understanding about bears, and shifting negative attitudes and behaviors to those in favor of supporting conservation action is the ultimate goal-and cultural beliefs and shared stories about bears can help reveal how to achieve this (Clark and Slocombe 2009).

The emotional appeal of bears, as shared through news media and other narratives, can also be a deeper representation of conservation issues such as habitat loss, species survival, and climate change, which may be useful in fostering empathy toward bears and encouraging desired behavior change (Swim and Bloodhart 2015, Young et al. 2015). The use of polar bears provides such an example, linking representations of climate change and the perils facing humanity with Arctic Indigenous culture and connection to the land (Swim and Bloodhart 2015, Born 2018). As suggested by Born (2018:10), the "icon of the polar bear localizes the global phenomenon of climate change [...] and further connects it to individual fate and suffering." Polar bear stories also share narrative elements with the utilitarianism theme, reflective of the role bears play in trophy hunting and eco-tourism in support of Arctic Indigenous culture and livelihoods (Foote and Wenzel 2009).

Utilitarian bear stories also have the potential to support conservation efforts by demonstrating respect through the use of taboos that designate normative behaviors and ethical conduct and an understanding of sustainability. Caution is advised, however, because some utilitarian narratives, such as those about the modern bear bile industry, might edge into unethical and exploitative territory (Hobson 2007). On the other hand, although hunters are typically depicted as utilitarian, a case study from Italy on brown bears found that hunters instead promoted the establishment of a park to protect bears (and Alpine chamois [Rupicapra rupicapra]; Glikman et al. 2019). Although local peoples' narratives of brown bears demonstrated limited knowledge about the species' biology and ecology, this does present an educational opportunity that conservation managers could develop to better promote brown bear conservation. Similarly, in examining stories about bears that express fear of these animals, conservationists could use this as an educational opportunity to dispel myths, avoid perpetuation of negative reactions toward bears, and instead "safely train us for the big challenges" (Gottschall 2012:58) in coexisting with bears.
For many, bear stories offer a way for humans to ponder the epistemological or philosophical questions about one's self or our place in the world, where contact with wild nature (including through story) is a necessary and important part of human development (Frank 2016). It is our hope then, that this review offers a starting point for bear conservationists to recognize and consider the important role that cultural narratives play in humanbear relations, and in turn, conservation efforts (Dhee et al. 2019, Lute and Carter 2020). Certainly, the enculturated stories people tell about bears, whether old tales or new, can affect our dispositions and actions toward these animals (Kellert 1994, Mattson et al. 2006, Frank et al. 2019). With this in mind, we offer practical suggestions for including bear stories to help develop locally appropriate and culturally sensitive conservation policy. We hope these suggestions not only have the potential to help achieve desired bear-conservation outcomes, but also build common interest, respect, trust, and legitimacy between groups of people working toward this end (Ingold 1994, Peterson et al. 2010, Infield et al. 2018, Dhee et al. 2019). These suggestions include the following:

- Participatory engagement of people and their values, whereby listening to and learning from people can help in developing policy language and content, and promote institutional buy-in across various governance levels;

- Following the above, learning about people's bear values through story has the benefit of helping to facilitate dialogue and develop understanding between different groups (e.g., researchers, conservationist, local communities), which in turn can help develop appreciation of each other and promote acceptance and implementation of conservation action;

- Continued use of bear symbolism or metaphor in designing policy interventions to share lessons (e.g., morality, empathy, safety, respect) through educational messaging that is relevant to local culture and context;

- Build understanding of concepts such as land sharing between people and bears, or ecological function and habitat management;

- Use stories to motivate people toward ethical choices and stewardship action; and,

- Develop policy that avoids unintended consequences, such as devaluing local culture, and instead recognizes its importance.

Certainly, explicit consideration of culturally significant stories about bears in conservation policy can help facilitate a constructive approach to achieving desired 
outcomes (Fernández-Llamazares and Cabeza 2018, Infield et al. 2018).

We also suggest that policy practitioners and mainstream conservationists become better versed in social science theories and methods, and engage experts in these fields to help design and implement effective and meaningful conservation interventions (Drury et al. 2011, Rust et al. 2017, Cinner 2018). Cultural anthropology, conservation psychology, ecocriticism, cultural theories, and political ecology are some examples of potentially useful disciplinary perspectives that may help articulate the complex relationships between humans and nature, and how this can translate to stories as well as to conservation policy (Clayton and Meyers 2009, Garrard 2012, Robbins 2012, Blicharska and Mikusinski 2014).

\section{Closing remarks}

As demonstrated by our qualitative exploratory review, bears are more than mere carnivores in human imagination, representative of iconic but contested symbols that have the potential to affect the trajectory of conservation policy (Black 1998). We believe the themes we present offer a starting point to acknowledge and incorporate the significance that the stories we tell about bears hold for conservation action (Ingold 1986, Wondolleck and Yaffee 2000, Knight 2001, Clayton and Meyers 2009, Waylen et al. 2009, Lescureux and Linnell 2010, Blicharska and Mikusinski 2014, Camino et al. 2016, Dhee et al. 2019). Certainly, if local cultural meanings, such as those transmitted through forms of story, are not better understood, contradictions between policy and public values and expectations can result in contentious management contexts (Mattson et al. 2006, Ciucci and Boitani 2008, Campbell and Lancaster 2010). Accordingly, the symbolic potency that different wild animals, such as bears, hold for people has the power to shape beliefs, values, and behaviors, including participation in and acceptance of conservation activities. Indeed, conservation policy needs to be developed to the scale and scope in which it is applied, which means soliciting and engaging people and their cultural beliefs in this work (Wondolleck and Yaffee 2000). In turn, the information and understandings gained can be utilized in collaborative approaches to help conservation practitioners identify and illuminate locally dominant discourses, deeprooted beliefs, and values, and ultimately craft effective policy that resonates with the needs of both bears and people.

\section{Acknowledgments}

We would like to thank the Associate Editor and reviewers for their time and contributions to improving our manuscript for publication.

\section{Literature cited}

BARBEAU, M. 1946. Bear mother. The Journal of American Folklore 59:1-12.

BASCOM, W. 1954. Four functions of folklore. The Journal of American Folklore 67:333-349. doi:10.2307/536411.

BAYNES-ROCK, M. 2015. Ethiopian Buda as hyenas: Where the social is more than human. Folklore 126:266-282.

Bhatia, S., S.M., RedPath, K., SuRtawanshi, AND C. MisHRA. 2019. Beyond conflict: Exploring the spectrum of human-wildlife interactions and their mechanisms. Oryx 108. doi: 10.1017.S003060531800159X.

BIEDER, R.E. 2007. Orso (Bear). Urra-Apogeo s.r.l., Milan, Italy.

BLACK, L.T. 1998. Bear in human imagination and ritual. Ursus 10:343-347.

BLICHARSKA, M., AND G. MIKUSINSKI. 2014. Incorporating social and cultural significance of large old trees in conservation policy. Conservation Biology 28:1558-1567.

BLOMBERG P.E. 2007. How did the constellation of the bear receive its name? Pages 129-132 in E. Pásztor, editor. Archaeoastronomy in archaeology and ethnography. Papers from the 2004 annual meeting of SEAC (European Society for Astronomy in Culture), Kecskemét, Hungary.

BORN, J.K. 2018. Bearing witness? Polar bears as icons for climate change communication in National Geographic. Environmental Communication 13:649-663. doi: 10.1080/17524032.2018.1435557.

BOWEN-Jones, E., AND A. ENTWISTLE. 2002. Identifying appropriate flagship species: The importance of culture and local contexts. Oryx 26:189-195.

BritTAin, S., H. IBbett, E. DE LANGe, L. DoRWARD, S. Hoyte, A. Marino, E.J. Milner-Gulland, J. Newth, S. RaKoTONARIVO, D. VERÍSSIMO, AND J. LEWIS. 2020. Ethical considerations when conservation research involves people. Conservation Biology. doi: 10.1111/cobi.13464.

BRONNER, S.J. 2007. The meaning of folklore: The analytical essays of Alan Dundes. Utah State University Press, Logan, Utah, USA.

BRUNNER, B. 2007. Bears: A brief history. Yale University Press, New Haven, Connecticut, USA.

Buckingham, K., J. NeIL, W. DaVID, AND P. JePSON. 2013. Diplomats and refugees: Panda diplomacy, soft "cuddly" power, and the new trajectory in panda conservation. Environmental Practice 15:262-270. DOI: 10.1017/S1466046613000185.

Camino, M., S. Cortez, A. Cerezo, and M. Altrichter. 2016. Wildlife conservation, perceptions of different coexisting cultures. International Journal of Conservation Science 7:109-122. 
CAMPBell, M., AND B. LANCASTER. 2010. Public attitudes toward black bears (Ursus americanus) and cougars (Puma concolor) on Vancouver Island. Society and Animals 18:40 57. doi: 10.1163/106311110X12586086158448.

CAN, Ö.E., N. D'CRUZE, D.L. GARshelis, J. BEECHAM, AND D.W. MACDONALD. 2014. Resolving human-bear conflict: A global survey of countries, experts, and key factors. Conservation Letters 7:501-513. doi:10.1111/conl.12117.

Carvalho, E., AND J. PezzuTI. 2010. Hunting of jaguars and pumas in the Tapajós-Arapiuns Extractive Reserve, Brazilian Amazonia. Oryx 44:610-612. doi:10.1017/S003060531000075X.

Chamberlain, E.C., M.B. Rutherford, AND M.L. GibeAu. 2012. Human perspectives and conservation of grizzly bears in Banff National Park, Canada. Conservation Biology 26:420-431.

CHILD, K.R., AND C.T. DARIMONT. 2015. Hunting for trophies: Online hunting photographs reveal achievement satisfaction with large and dangerous prey. Human Dimensions of Wildlife 20:531-541.

CINNER, J. 2018. How behavioral science can help conservation. Science 362:889-890. doi: 10.1126/science.aau6028.

CIUCCI, P., AND L. BoITANI. 2008. The Apennine brown bear: A critical review of its status and conservation problems. Ursus 19:130-145. doi: 10.2192/07PER012.1.

ClarK, D.A., AND D.S. Slocombe. 2009. Respect for grizzly bear: An Aboriginal approach for co-existence and resilience. Ecology and Society 14(1):42.

Clark, S.G., AND M.B. RUTHERFORD. 2014. Large carnivore conservation: Integrating science and policy in the North American West. The University of Chicago Press, Chicago, Illinois, USA.

CLARK, T.W. 2002. The policy process: A practical guide for natural resource professionals. Yale University Press, New Haven, Connecticut, USA.

Clayton, S., and G. Meyers. 2009. Conservation psychology: Understanding and promoting human care for nature. Blackwell Publishing, Oxford, England, UK.

De Pinho, J.R., C. Grilo, R.B. Boone, K.A. Galvin, AND J.G. SNODGRASS. 2014. Influence of aesthetic appreciation of wildlife species on attitudes towards their conservation in Kenyan agropastoralist communities. PLoS ONE 9(2):e88842. doi: 10.1371/journal.pone.0088842.

DESCOLA, P. 1996. Constructing natures: Symbolic ecology and social practice. Pages 82-102 in P. Descola and G. Palsson, editors. Nature and society: Anthropological perspectives. Routlegde, London, England, UK.

DHEE, V.A., J.D.C. LinNELl, S. ShIVAKumar, AND S.P. DHIMAN. 2019. The leopard that learnt from the cat and other narratives of carnivore-human coexistence in northern India. People and Nature 00:1-11. doi: 10.1002/pan3.10039.

Dickman, A., P.J. JoHnson, F. VAN Kesteren, AND D.W. MACDONALD. 2015. The moral basis for conservation: How is it affected by culture? The Ecological Society of America 13:325-331. doi:10.1890/140056.
DiCKMAN, A.J. 2010. Complexities of conflict: The importance of considering social factors for effectively resolving human-wildlife conflict. Animal Conservation 13:458-466.

DRESSEL, S., C. SANDSTRÖM, AND G. ERICSSON. 2015. A metaanalysis of studies on attitudes toward bears and wolves across Europe 1976-2012. Conservation Biology 29:1-10. DOI:10.1111/cobi.12420.

Drury, R., HomewoOd, K., AND S. RANDALl. 2011. Less is more: The potential of qualitative approaches in conservation research. Animal Conservation 14:18-24. doi: 10.1111/j.1469-1795.2010.00375.x.

DUNHAM, M. 2007. The hyena: Witch's auxiliary or nature's fool? Witchcraft and animal lore amongst the Valengi of Tanzania. Pages 586-595 in E. Dounias, E. Motte-Florac, and M. Dunham, editors. Animal symbolism: Animals, keystone in the relationship between man and nature? Institute de Recherche pour le Dévelopment, Paris, France.

ELMS, A.C. 1977. The three bears: Four interpretations. The Journal of American Folklore 90(357):257-273.

FERnÁNDEZ-LlamAZARES, Á., AND M. CABEZA. 2018. Rediscovering the potential of indigenous storytelling for conservation practice. Conservation Letters 11(3):e12398. doi: 10.1111/conl.12398.

FIGARI, H., AND K. SKOGEN. 2011. Social representations of the wolf. Acta Sociologica 54:1-16.

FOLTZ, R. 2010. Zoroastrian attitudes toward animals. Society and Animals 18:367-378.

FoOTE, L., AND G.W. WENZEL. 2009. Polar bear conservation hunting in Canada: Economics, culture and unintended consequences. Pages 13-24 in M.M.R. Freeman and L. Foote, editors. Inuit, polar bears, and sustainable use: Local, national and international perspectives. CCI Press, University of Alberta, Edmonton, Alberta, Canada.

ForT, J.L., C.K. NiElsen, A.D. CARVER, R. MORENO, AND N.F. MEYER. 2018. Factors influencing local attitudes and perceptions regarding jaguars Panthera onca and National Park conservation in Panama. Oryx 52:282-291. doi: 10.1017/S0030605317001016.

FrANK, B.F., J.A. GLIKMAN, AND S. MARCHINI. 2019. Humanwildlife interactions: Turning conflict into coexistence. Cambridge University Press, Cambridge, England, UK.

FRANK, R. 2015. "Shamanism in Europe? Three ritual healers: The Basque salutariyua, the French marcou and the Italian maramao." Academia.edu. https://books.openedition. org/aaccademia/1377.

. 2016. Paul Shepard's "Bear Essay": On environmental ethics, deep ecology and our need for the other-thanhuman animals. https:/www.academia.edu/29619795/ Paul_Shepards_Bear_Essay_On_Environmental_Ethics_ Deep_Ecology_and_Our_Need_for_the_Other-thanHuman_Animals. Accessed 22 Mar 2020.

—, AND F. SILVA. 2012. European folklore in the longue durée: Paleolithic continuity and the European ursine genealogy. Presentation at the Folklore and Archaeology Conference, 13-14 Oct 2012, University College London, Lon-

Ursus 31:article e15 (2020) 
don, England, UK. http://tinyurl.com/folklore-longueduree. Accessed 3 Jun 2020.

Frank, S.C., O. Andres, J. Gosselin, A. Hertel, J. KindBERG, M. LECLERC, F. PELlETIER, S.M.J.G. STEYAERT, OG. Stoen, J. Van de Walle, A. Zedrosser, And J.E. SWENSON. 2017. Indirect effects of bear hunting: A review from Scandinavia. Ursus 28:150-164.

Fraser, J., D. Reiss, P. Boyle, K. Lemcke, J. Sickler, E. Elliot, B. Newman, AND S. GRUBer. 2006. Dolphins in popular literature and media. Society and Animals 14: 321-350.

Fraser-Celin, V.L., A.J. HovORKA, AND J.J. Silver. 2018. Human conflict over wildlife: Exploring social constructions of African wild dogs (Lycaon pictus) in Botswana. Human Dimensions of Wildlife 23:341-358. doi:10.1080/10871209.2018.1443528.

Fritts, S., R. Stephenson, R. HAYES, AND L. Boitani. 2003. Wolves and humans. In D. Mech and L. Boitani, editors. Wolves: Behavior, ecology, and conservation. University of Chicago Press, Chicago, Illinois, USA. https://digitalcommons.unl.edu/usgsnpwrc/317/. Accessed 3 Jun 2020.

GARRARD, G. 2012. Ecocriticism: The new critical idiom. Routledge, New York, New York, USA.

GERGEN, K.J. 2015. An invitation to social construction. Third edition. Sage Publications, London, England, UK.

GIBBON, W. 1964. Asiatic parallels in North American star lore: Ursa Major. The Journal of American Folklore 77:236-250. https://doi.org/10.2307/537746.

Glikman, J.A., P. CiUCCI, A. MARino, E.O. DAVIS, A.J. BATH, AND L. BoITANI. 2019. Local attitudes toward Apennine brown bears: Insights for conservation issues. Conservation Science and Practice 1(5):e25. doi: 10.1111/csp2.25.

- J.J. VASKe, A.J. BATH, P. CIUCCI, AND L. BoITANI. 2012. Residents' support for wolf and bear conservation: The moderating influence of knowledge. European Journal of Wildlife Research 58:295-302.

Good, C., D. Burnham, and D.W. Macdonald. 2017. A cultural conscience for conservation. Animals 7:52. doi:10.3390/ani7070052.

GotTschall, J. 2012. The storytelling animal: How stories make us human. Houghton Mifflin Harcourt, New York, New York, USA.

GRAYSON, K. 2012. How to read Paddington Bear: Liberalism and the foreign subject in a bear called Paddington. The British Journal of Politics and International Relations 15:378-393.

HaddaWAy, N.R., P. WoOdCOCK, B. Macura, AND A. COLLINS. 2015. Making literature reviews more reliable through application of lessons learned from systematic reviews. Conservation Biology 29:1596-1605.

Hall, D.M., S.J. Gilbertz, C.C. Horton, AND T.R. PeterSON. 2012. Culture as a means to contextualize policy. Journal of Environmental Studies and Science 2:222-233. doi:10.1007/s13412-012-0077-9.
HARDING, L. 2014. What good is a bear to society? Society \& Animals 22:174-193.

HAREL, N. 2009. The animal voice behind the animal fable. Journal of Critical Animal Studies 7:9-21.

HARTIG, F. 2013. The cutest part of China's public diplomacy. The Hague Journal of Diplomacy 8:49-78.

Head, L., D. Trigger, And J. Mulcock. 2005. Culture as concept and influence in environment research and management. Conservation and Society 3:251-264.

HILl, C.M. 2015. Perspectives of "conflict" at the wildlife-agriculture boundary: 10 years on. $\mathrm{Hu}-$ man Dimensions of Wildlife 20:296-301. doi: 10.1080/10871209.2015.1004143.

—, AND A.D. WEBBER. 2010. Perceptions of nonhuman primates in human-wildlife conflict scenarios. American Journal of Primatology 72:919-924.

HoBson, K. 2007. Political animals? On animals as subjects in an enlarged political geography. Political Geography 26:250-267.

Hughes, C., AND S.E. NiELSEN. 2019. 'Bear are only the lightning rod': Ongoing acrimony in Alberta's grizzly bear recovery. Society and Natural Resources 32:34-52. doi:10.1080/08941920.2018.1502853.

- N. YARMEY, A. Morehouse, AND S. NIELSEN. 2020. Problem perspectives and grizzly bears: A case study of Alberta's grizzly bear recovery policy. Frontiers in Ecology and Evolution 8:38. doi: 10.3389/fevo.2020.00038.

Infield, M., A. EnTwistle, H. ANTHEM, A. Mugisha, AND K. PHILLIPS. 2018. Reflections on cultural values approaches to conservation: Lessons from 20 years of implementation. Oryx 52:220-230. doi: 10.1017/S0030605317000928.

INGOLD, T. 1986. The appropriation of nature: Essays on human ecology and social relations. University of Iowa Press, Iowa City, Iowa, USA.

. 1994. What is an animal? Routledge, Oxford, England, UK.

IVES, C.D., M. GiUsti, J. Fischer, D.J. ABSON, K. KLANIECKI, C. Dorninger, J. Laudan, S. BArthel, P. Abernethy, B. Martín-López, C.M. RaYmond, D. Kendal, And H. WEHRDEN. Human-nature connection: A multidisciplinary review. Current Opinion in Environmental Sustainability 26-27:106-113. doi: 10.1016/j.cosust.2017.05.005.

JALAIS, A. 2008. Unmasking the cosmopolitan tiger. Nature and Conservation 3:25-40.

JANOUŠKOVÁ, Z. 2007. Conservation and bears in Canadian literature. Thesis (unpublished), Masaryk University, Brno, Czech Republic.

JONES, M.O. 1994. Putting folklore to use. University Press of Kentucky, Lexington, Kentucky, USA.

Kaczensky, P., M. Blazic, And H. Gossow. 2004. Public attitudes towards brown bears (Ursus arctos) in Slovenia. Biological Conservation 118:661-674.

KELlERT, S.R. 1994. Public attitudes toward bears and their conservation. International Conference on Bear Research and Management 9:43-50. 
KING, G. 2012. The history of the teddy bear: From wet and angry to soft and cuddly. Smithsonian Magazine. www.smithsonianmag.com. Accessed 19 Oct 2016.

KNIGHT, C. 2000. The moon bear as a symbol of Yama: Its significance in the folklore of upland hunting in Japan. Asian Ethnology 67:79-101.

KNIGHT, J. 2001. Natural enemies: People-wildlife conflicts in anthropological perspective. Routledge, London, England, UK.

LESCUREUX, N., AND J.D.C. LINNELL. 2010. Knowledge and perceptions of Macedonian hunters and herders: The influence of species specific ecology of bears, wolves and lynx. Human Ecology 38:389-399.

LUTE, M.L., AND N.H. CARTER. 2020. Are we coexisting with carnivores in the American west? Frontiers in Ecology and Evolution 8(48). doi: 10.3389/fevo.2020.00048.

MADDEN, F. 2004. Can traditions of tolerance help minimize conflict? An exploration of cultural factors supporting human-wildlife coexistence. Policy Matters 13:234-241.

MAJASAN, J.A. 1969. Folklore as an instrument of education among the Yoruba. Folklore 80:41-59. doi: 10.1080/0015587X.1969.9716616.

MATEJOVA, M. 2015. Is global activism saving the polar bear? Environment: Science and Policy for Sustainable Development 57:14-23.

MatTsOn, D.J., K.L. BYrd, M.B. Rutherford, S.R. Brown, T.W. AND CLARK. 2006. Finding common ground in large carnivore conservation: Mapping contending perspectives. Environmental Science and Policy 9:392-405.

Mclellan, B.N., M.F. Proctor, D. Huber, AND S. MICHEL. 2017. Ursus arctos (amended version of 2017 assessment). The IUCN Red List of Threatened Species 2017: e.T41688A121229971. https://dx.doi.org/ 10.2305/IUCN.UK.2017-3.RLTS.T41688A121229971.en. Accessed on 12 Jun 2020.

Morehouse, A.T., C. Hughes, N. Manners, J. Bectell, AND T. BRUDER. 2020. Carnivores and communities: A case study of human-carnivore conflict mitigation in southwestern Alberta. Frontiers in Ecology and Evolution 8:2. doi: 10.3389/fevo.2020.00002.

MuKul, S.A., A.Z.M.M. RASHID, AND M.B. UDDIN. 2012. The role of spiritual beliefs in conserving wildlife species in religious shrines of Bangladesh. Biodiversity 13:108-114. doi: 10.1080/14888386.2012.694596.

Mullin, M.H. 1999. Mirrors and windows: Sociocultural studies of human-animal relationships. Annual Review of Anthropology 28:201-224. doi: 10.1146/annurev.anthro.28.1.201.

Pastourneau, M. 2011. The bear: History of a fallen king. Belknap Press of Harvard University Press, Cambridge, Massachusetts, USA.

Peterson, R.B., D. Russell, P. West, AND J.P. BroSIUS. 2010. Seeing (and doing) conservation through cultural lenses. Environmental Management 45:5-18. doi: 10.1007/s00267-008-9135-1.
PRETTY, J., AND D. SMITH. 2004. Social capital in biodiversity conservation and management. Conservation Biology 18:631-638. doi 10.1111/j.1523-1739.2004.00126.x.

RAMSEY, M.S. 1997. The bear book: Readings in history and evolution of gay male subculture. Haworth Gay \& Lesbian Studies. Harrington Park Press, New York, New York, USA.

RAN, J., B. DU, AND B. YUE. 2009. Conservation of the endangered giant panda Ailuropoda melanoleuca in China: Successes and challenges. Oryx 43(2):176-178. DOI:10.1017/S0030605309432010.

RedPath, S.M., S. Bhatia, AND J. Young. 2015. Tilting at wildlife: Reconsidering human-wildlife conflict. Oryx 49:222-225.

RICHIE, L., J.D. OPPENHEIMER, AND S.G. CLARK. 2012. Social process in grizzly bear management: Lessons for collaborative governance and natural resource policy. Policy Sciences 45:265-291.

RILEY, E.P. 2010. The importance of human-macaque folklore for conservation in Lore Lindu National Park, Sulawesi, Indonesia. Oryx 44:235-240.

RobBIns, P. 2012. Political ecology: A critical introduction. Second edition. John Wiley \& Sons Ltd., The Atrium, Southern Gate, Chichester, West Sussex, England, UK.

RoE, P.G. 1998. Chapter 7. Paragon or peril: The jaguar in Amazonian Indian Society. Pages 171-197 in N.J. Saunders, editor. Icons of power: Feline symbolism in the Americas. Routlegde, London, England, UK.

Rust, N.A., A. Abrams, D.W.S. Challender, G. Chapron, A. Ghoddousi, J.A. Glikman, C.H. Gowan, C. Hughes, A. Rastogi, A. SAID, A. SutTon, N. TAYlor, A. ThOMAS, H. UNNIKRISHNAN, A.D. WEBBER, G. WORDINGHAM, AND C.M. HILL. 2017. Quantity does not always mean quality: The importance of qualitative social science in conservation research. Society and Natural Resources 30:1304-1310. doi: 10.1080/08941920.2017.1333661.

SCHNEIDER, H. 2018. Culture and conservation: A reply to Chua. Oryx 52:417.

SHEPARD, P., AND B. SANDERS. 1985. The sacred paw: The bear in nature, myth and literature. Viking Penguin Inc., New York, New York, USA.

SousA, J., A. AINSLE, AND C.M. HILL. 2018. Sorcery and nature conservation. Environmental Conservation 45:90-95. doi: 10.1017/S0376892917000327.

STAKER, A. 2017. Should chimpanzees have standing? The case for pursuing legal personhood for non-human animals. Transnational Environmental Law 6:485-507. doi: 10.1017/S204710251700019X.

Swim, J.K., AND B. BloodharT. 2015. Portraying the perils to polar bears: The role of empathic and objective perspective-taking toward animals in climate change communication. Environmental Communication 9(4):446-468. DOI: $10.1080 / 17524032.2014 .987304$.

TATAR, M., editor. 2002. The annotated classic fairy tales. W.W. Norton and Company, New York, New York, USA.

Ursus 31:article e15 (2020) 
TEGEL, S. 2011. Why the day of the condor could be drawing to a close. The Independent. www.independent.co.uk/ environment/nature/why-the-day-of-the-condor-could-bedrawing-toa-close-2331401.html. Accessed 24 Jul 2018.

VARGA, D. 2009. Babes in the woods: Wilderness aesthetics in children's stories and toys, 1830-1915. Society and Animals 17:187-205.

WALSH, M., AND H. GOLDMAN. 2012. Chasing imaginary leopards: Science, witchcraft and the politics of conservation in Zanzibar. Journal of Eastern African Studies 6:727-746.

WAYlen, K.A., A. Fisher, P.K. McGowan, S.J. ThIRGOOD, AND E.J. MiLNER-GuLLAND. 2009. Effect of local cultural context on the success of community-based conservation interventions. Conservation Biology 24:1119-1129.

Werness, H.B. 2004. The Continuum encyclopedia of animal symbolism in art. Continuum International Publishing Group, New York, New York, USA.

WILSON, S.M., G.A. NeUdECKER, AND J.J. JONKEL. 2014. Human-grizzly bear coexistence in the Blackfoot River watershed, Montana: Getting ahead of the conflict curve. Pages 177-214 in S.G. Clark and M.B. Rutherford, editors. Large carnivore conservation: Integrating science and policy in the North American West. University of Chicago Press, Chicago, Illinois, USA.

WONDOLLECK, J.M., AND S.L. YAFFEE. 2000. Making collaboration work: Lessons from innovation in natural resource management. Island Press, Washington, D.C., USA.
Yoon, H. 1979. Folklore and the study of environmental attitudes. Annals of the Association of American Geographers 69:635-637. doi: 10.1111/j.1467-8306.1979.tb01287.x.

YounG, A., K.A. KHALIL, AND J. WHARTON. 2018. Empathy for animals: A review of the existing literature. Curator: The Museum Journal 61:327-343. doi: 10.1111/cura.12257.

Young, J.K., Z. MA, A. LAUDATI, AND J. BERGER. 2015. Human-carnivore interactions: Lessons learned from communities in the American West. Human Dimensions of Wildlife 20:349-366.

ZEMMELMAN, S. 2012. A northern journey: Spirit of the bear, soul of a man. Jung Journal 6:7-27. DOI:10.1525/jung.2012.6.2.7.

ZIMMERMANN, A., M.J. WALPOLE, AND N. LEADER-WILLIAMS. 2005. Cattle ranchers' attitudes to conflicts with jaguar Panthera onca in the Pantanal of Brazil. Oryx 39: 406-412.

Received: January 27, 2019

Accepted: April 23, 2020

Associate Editor: A. Ordiz

\section{Supplemental material}

A. Literature reviewed 